\section{Dialogismo e Construção de Sentidos em Charges da Folha de São Paulo}

\author{
Dialogism and Construction of Meanings in Charges of \\ the Folha de São Paulo
}

\section{Amanda Mikaelly Nobre de Souza (D) 9}

amandasouza1997@outlook.com

Universidade do Estado do Rio Grande do Norte - UERN

\section{Ivaneide Gonçalves de Brito (iD) 9 \\ ivaneidegbrito@hotmail.com}

Universidade do Estado do Rio Grande do Norte - UERN

\section{Lidiane de Morais Diógenes Bezerra (D) 9 \\ lidmoraisb@gmail.com}

Universidade do Estado do Rio Grande do Norte - UERN

\section{Resumo}

Considerando o dialogismo inerente a qualquer manifestação da linguagem, sendo, portanto, condição para a construção de efeitos de sentidos do texto, neste artigo, objetiva-se analisar, a partir da manifestação das relações dialógicas, como os sentidos são construídos em charges da Folha de São Paulo. O corpus desta investigação, qualitativa e de ordem descritiva, é constituído de quatro charges de cunho político, referentes à figura do presidente Jair Bolsonaro, produzidas no mês de janeiro, do ano de 2020, veiculadas no Jornal Folha de São Paulo. Para isso, fundamentamo-nos teoricamente nos estudos de Bakhtin (2016, 2018), Volóchinov (2018) e de outros pesquisadores da obra bakhtiniana (BRAIT, 2005, 2016; MIOTELO, 2008), considerando, especificamente, as reflexões em torno da linguagem, do dialogismo e da ideologia. Em função disso, constatamos que o gênero em questão possibilita observar a manifestação das relações dialógicas, com base do (re)conhecimento do cronotopo, que situa e motiva a produção dos enunciados nele materializados, num processo de agenciamento da multiplicidade de vozes que evoca. Ademais, os sentidos no gênero também são construídos graças à natureza ideológica a ele inerente, reflexo do modo de pensar dos sujeitos e resultante das interações sociais e dialógicas, emergidas, no caso, do corpus analisado, pelo verbal e pelo visual.

\section{Palavras-chave}

Linguagem; Relações dialógicas; Sentidos; Charge; Folha de São Paulo.

\section{Abstract}

Considering the dialogism inherent in any manifestation of language, being, therefore, a condition for the construction of the effects of the text's meanings, this article aims to analyze, from the manifestation of dialogical relations, how the senses are constructed in Folha de São Paulo. The corpus of this investigation, qualitative and descriptive, consists of four political cartoons, referring to the figure of President Jair Bolsonaro, produced in the month of January, in the year 2020, published in the Folha de São Paulo newspaper. For this, we theoretically base ourselves on the studies of Bakhtin (2016, 2018), Volóchinov (2018) and other researchers of the Bakhtinian work (BRAIT, 2005, 2016; MIO-

\section{Linguagem Foco}

Revista do Programa de Pós-Graduação em Linguistica Aplicada da UECE

FLUXO DA SUBMISSÃO

Submissão do trabalho: $16 / 10 / 2020$ Aprovação do trabalho: 25/11/2020 Publicação do trabalho: 22/01/2021

\section{COMO CITAR}

SOUZA, Amanda Mikaelly Nobre de; BRITO, Ivaneide Gonçalves de; BEZERRA, Lidiane de Morais Diógenes. Dialogismo e Construção de Sentidos em Charges da Folha de São Paulo. Revista Linguagem em Foco, v.12, n.3, 2020. p. 238-259. Disponível em: https://revistas.uece.br/index.php/linguagememfoco/article/ view/4227.

Distribuído sob

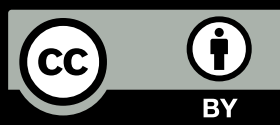


TELO, 2008), specifically considering the reflections around language, dialogism and ideology. As a result, ased on that, we found that the genre in question makes it possible to observe the manifestation of dialogical relationships, based on the (re) knowledge of the chronotope, which situates and motivates the production of the statements materialized therein, in a process of managing the multiplicity of voices it evokes. Furthermore, the meanings in the genre are also constructed thanks to the inherent ideological nature, reflecting the subjects' way of thinking and resulting from social and dialogical interactions, which emerged, in the case of the analyzed corpus, by the verbal and the visual.

Keywords

Language; Dialogical relations; Senses; Cartoon; Folha de São Paulo.

\section{Introdução}

Conceber a linguagem como uma manifestação social de natureza permanentemente dialógica, entre discurso e sociedade, implica assumir, em grande parte, os postulados de Bakhtin e seu Círculo', que discutem acerca de um dos conceitos basilares da teoria do grupo: o dialogismo.

Ademais, o presente artigo adota o pressuposto de que a discussão em torno do dialogismo compreende a relação entre sujeito e ideologia - conceitos que se inter-relacionam. Isso porque o próprio Bakhtin, ao discutir linguagem como a interação entre indivíduos, entende que o sujeito se constitui no e pelo discurso, através das práticas sociais, bem como dos diálogos que realiza com discursos e interlocutores outros, sejam eles convergentes ou divergentes, mas, de todo modo, dialógicos.

Os diálogos entre interlocutores e enunciados e entre os próprios enunciados são imprescindíveis para a construção de sentidos, pois evoca discursos e contextos, à medida que emergem de enunciados anteriores e suscitam tantos outros. Nisso, a palavra é valorativa, quando usada, recebe as marcas sociais e valorativas de uma época, de uma posição histórica, do lugar de fala do sujeito enunciador (VOLOCHINÓV, 2018).

Com efeito, é exatamente nesse atravessamento de enunciados, vozes e discursos outros que Bakhtin $(2004,2016)$ e seus estudiosos, a exemplo de Brait $(2005,2016)$, tratam das relações dialógicas que perpassam todos os outros conceitos apresentados pelo Círculo. Por essa assertiva, neste artigo, trabalhamos com o pressuposto de que a apreensão dos sentidos de um texto dar-se-á em íntima relação com a realidade social situada.

Assumimos como conceito de texto a mesma definição difundida por

1 Utiliza-se a expressão "Círculo de Bakhtin" porque, para além do próprio Bakhtin (1895-1975), as ideias e os conceitos são produtos de reflexão, de estudo e de pesquisa de um grupo do qual participavam outros intelectuais, a exemplo de Volóchinov (1895-1936), Medvedev (1892-1938), Kanaev (1893-1983), Kagan (18891934), Pumpianskii (1891-1940), Yudina (1899-1970), Vaguinov (1899-1934), Sollertinski (1902-1944) e Zubakin (1894-1937), como lembram Brait e Campos (2009). 
Bakhtin (2016), de texto como enunciado concreto, constituindo um elo na comunicação discursiva. Nos textos, estão contidos, segundo o autor, dois elementos que fazem dele um enunciado: a sua intenção comunicativa e a concretização dessa intenção.

Partindo da perspectiva de que o dialogismo é inerente a qualquer manifestação da linguagem, sendo, portanto, condição para a construção de sentidos do texto, este artigo tem como objetivo descrever e analisar, a partir da manifestação das relações dialógicas, como os sentidos são construídos em charges da Folha de São Paulo, com respaldo nos postulados de Bakhtin e do Círculo a respeito do dialogismo e das visões ideológicas neles materializados.

A escolha do gênero charge deu-se em razão da nossa pretensão em analisar textos voltados para a situação política atual, mais precisamente para a figura do Presidente Jair Bolsonaro, veiculados pela mídia jornalística, cuja abordagem mesclasse ironia, humor e crítica, mas que, sobretudo, tratassem de assuntos relevantes à sociedade, com impacto sobre diferentes áreas, como economia, cultura, meio ambiente e educação.

É largamente aceita a tese de que a proposição do caráter dialógico da linguagem é uma das contribuições mais importantes (senão a mais importante) de Bakhtin e o seu Círculo para os estudos da linguagem. Isso porque as noções sobre o dialogismo servem para esclarecer a compreensão acerca de outros conceitos formulados pelo grupo bakhtiniano, a exemplo da ideologia, também discutida neste trabalho, ainda que brevemente. Daí, a relevância de compreender a manifestação do dialogismo na construção de sentidos do gênero charge, que "apresenta como que uma tirada conclusiva, uma réplica a respeito de um dado evento social, supostamente público e notório" (FLÔRES, 2002, p. 14).

Além disso, argumentamos que as charges, enquanto textos multissemióticos, multimidiáticos e jornalísticos por excelência, dialogam com outros textos e, portanto, outros discursos, em uma relação interdiscursiva, visto que são construídas a partir de uma dada situação enunciativa. Elas reproduzem, geralmente por meio de uma crítica social, o que se passa em uma determinada sociedade e em um determinado tempo. Assim, o trabalho se justifica, ainda, na medida em que aborda as práticas discursivas da sociedade com vistas à construção dos sentidos.

De modo a elucidar esta investigação, organizamos o artigo em cinco partes: i) estas palavras introdutórias; ii) reflexão acerca do aparato teórico que dá sustentação ao estudo, promovendo uma discussão a respeito dos conceitos de 
linguagem, texto e dialogismo em Bakhtin e no Círculo, conforme literatura selecionada; iii) explanação dos aspectos metodológicos que subsidiam o trabalho analítico; iv) análise referente à construção dos efeitos de sentidos em textos verbo-visuais do gênero charge, a partir das relações dialógicas nele materializadas; e, por fim, v) síntese dos resultados alcançados com o presente estudo, por meio de algumas considerações.

\section{As concepções de linguagem, texto e dialogismo em Bakhtin e no Círculo}

Nos estudos do pensador russo Mikhail Bakhtin e do Círculo, a linguagem é entendida numa perspectiva social, pelo fato de o grupo compreender que seu conceito é amplo e vai muito além do linguístico. É, pois, para além de uma teoria, uma visão de mundo acerca da linguagem, que é construída e adquirida socialmente. Corroboramos com Brait $(2005$, p. 93) quando diz que "[...] a linguagem não é centrada no vazio, mas numa situação histórica e social concreta no momento e no lugar da atualização do enunciado".

Nesse viés, a autora compreende que a linguagem, de natureza inerentemente social, é constituída de interação e envolve, pois, fatores contextuais. Para Bakhtin, a interação ocorre em um quadro de relações (enunciador e coenunciador), de forma social, cultural e historicamente marcada. Ou seja, quem fala, fala de algum lugar, dentro de um algum contexto histórico, social, ideológico e cultural, o que torna coerente dizer que a linguagem mobiliza o permanente diálogo entre indivíduo e sociedade.

A respeito da relação espaço-tempo no âmbito do texto literário, Bakhtin (2014) institui a noção de cronotopo, categoria que determina os gêneros e suas modalidades, dada a sua legítima presença. Nas palavras do autor, "à interligação fundamental das relações temporais e espaciais, artisticamente assimiladas em literatura, chamaremos de cronotopo" (BAKHTIN, 2014, p. 211). Foi na literatura que Bakhtin propôs o desenvolvimento desse conceito, elegendo o romance como o grande campo de estudo das relações cronotópicas. Contudo, não somente nas artes fica evidente a importância do legado bakhtiniano para a representação do tempo e do espaço, mas nos textos e nos discursos em geral.

O conceito de linguagem, em Marxismo e Filosofia da Linguagem, é associado ao acontecimento social da interação discursiva, que "ocorre por meio de um ou de vários enunciados" (VOLÓCHINOV, 2018, p. 219). Nesse sentido, falar em interação implica falar em acontecimento, em enunciados socialmente orientados. A linguagem é, portanto, tida como o produto da interação entre dois 
ou mais indivíduos socialmente organizados, que, ao fazer uso dela, recorrem a signos constitutivamente ideológicos.

Acerca disso, Brait (2005, p. 97) acrescenta que "[...] o ouvido do leitor é sempre provocado por um conjunto de vozes, nem sempre harmoniosas, que apontam insistentemente para a natureza constitutivamente dialógica da linguagem", ou seja, ainda que divergentes, dialogam entre si. Interessa-nos, então, uma concepção de linguagem que, para a construção dos sentidos, são necessariamente considerados os sujeitos e a sua inscrição social, isto é, como se encontram historicamente situados.

Tal modo de conceber a linguagem coaduna com o conceito de texto adotado por Bakhtin: uma realidade imediata do pensamento e das vivências, manifestada num conjunto coerente de signos (BAKHTIN, 2016). No entendimento de texto como enunciado, o autor supracitado entende que há dois elementos que determinam o gênero e suas modalidades: a intenção, que motiva a sua produção, e o que é feito para que essa intenção se realize. Por esse pressuposto, corroboramos que "cada texto (como enunciado) é algo individual, único e singular, e nisso reside todo o seu sentido (a sua intenção em prol da qual ele foi criado)" (BAKHTIN, 2016, p. 74).

A respeito do conceito de texto, nos estudos bakhtinianos, Brait (2016), em O texto nas reflexões de Bakhtin e do Círculo, entende texto enquanto um construto linguístico que, situado em um cronotopo específico, apresenta, explícita e implicitamente, diálogos com interlocutores inseridos socialmente em diferentes tempos.

Essa concepção de texto, ainda nas palavras de Brait (2016), implica considerar, teórico e metodologicamente, três universos: i) materialidade, que garante vida ao texto; ii) singularidade, que configura o texto como único, pois diz respeito ao contexto ao qual este pertence; iii) condição advinda dessa combinatória, que suscita novos diálogos com outros textos. A autora ressalta que esses três universos estão constitutivamente articulados quando se pensa o texto na perspectiva dos estudos de Bakhtin e do Círculo.

É preciso, assim, entender o dialogismo como um elemento constitutivo do texto, manifestado em qualquer tipo de linguagem, uma vez que a própria vida humana é de natureza dialógica: sentimos, pensamos, agimos, interrogamos, respondemos, concordamos, discordamos etc. Nessas constantes, o homem constitui-se do outro e do meio social em que habita, o que implica dizer que seus discursos são sempre respostas aos discursos de outros sujeitos, e, con- 
sequentemente, à medida que são incorporados pelo sujeito que enuncia, originam novos discursos.

Em outras palavras, o dialogismo discutido por Bakhtin não se volta apenas para a linguagem, mas para o mundo como um todo, pois é impossível analisar qualquer aspecto do mundo longe das suas relações dialógicas com a história, com a sociedade e com o próprio homem, realizando-se como "o diálogo infinito e inacabável em que nenhum sentido morre" (BAKHTIN, 2003, p. 410), caracterizando o que o autor definiu de "grande tempo".

Mediante asserções acerca das ideias que norteiam a concepção de Bakhtin e do Círculo sobre a linguagem, já podemos perceber que as relações dialógicas estabelecem sentidos aos textos, como enunciados, pois elas são, na verdade, as próprias relações de sentido, nomeadas pela literatura de dialogismo.

A esse respeito, o filósofo russo diz que "[...] cada enunciado é um elo na corrente complexamente organizada de outros enunciados" (BAKHTIN, 2016, p. 26) e que o texto subjaz alteridade, "sempre se desenvolve na fronteira de duas consciências, de dois sujeitos" (BAKHTIN, 2016, p. 76, grifos do autor). Assim, argumentamos que a orientação dialógica volta-se para dois eixos: primeiro, os enunciados mantêm relações com outros, isto é, dentro das nossas vozes, há a presença de outras vozes; segundo, os enunciados são sempre orientados para alguém, para o outro, para o interlocutor.

Por essa assertiva, o diálogo é entendido como constitutivo da linguagem em sentido amplo, e não apenas da linguagem verbalizada oralmente (face a face), uma vez que ocorre até mesmo quando o outro não está presente fisicamente. Sob esse prisma, em uma obra, por exemplo, os enunciados estão materializados, os sujeitos em diálogo não são físicos e as discussões são realizadas de modo que devam ser compreendidas, sendo que, segundo Bakhtin (2016), a própria compreensão já é dialógica.

É preciso entender, ainda, que só é possível estabelecer relações dialógicas quando se leva em consideração os aspectos extralinguísticos, que ampliam o horizonte dialógico da interação, dado que, na superfície textual, pode-se verificar apenas os de caráter proeminentemente linguísticos. Além disso, conforme Brait (2005, p. 95), as relações dialógicas "se estabelecem entre o eu e o outro nos processos discursivos instaurados historicamente pelos sujeitos, que, por sua vez, se instauram e são instaurados por esses discursos". Ou seja, somos alterados pelo discurso do outro e alteramos o discurso construído pelo outro todo o tempo, de modo que, na verdade, somos uma constituição do outro.

Intrinsecamente relacionadas à construção dos sentidos, as relações dia- 
lógicas, enquanto "manifestação de diferentes vozes no jogo da comunicação discursiva", são complexas, remetem, pois, a uma pluralidade de sentidos que, necessariamente, perpassa pelo plano do dialogismo (BESSA, 2016, p. 19). Entendamos, portanto, que a construção de sentidos se dá sempre de maneira dialógica e perpassa o plano da significação, que

[...] pertence a uma palavra enquanto traço de união entre os interlocutores, isto é, ela só se realiza no processo de compreensão ativa e responsiva. A significação não está na palavra nem na alma do falante, assim como também não está na alma do interlocutor. Ela é efeito da interação do locutor e do receptor produzido através do material de um determinado complexo sonoro. (VOLÓCHINOV, 2018, p. 232-233, grifos do autor).

Ao sustentar a noção de que o discurso tem eminentemente uma natureza dialógica, Bakhtin (2016) postula que o enunciado se volta a duas orientações: ao já dito e a uma resposta. Noutras palavras, para que ocorra a interação, o indivíduo parte do já dado para, a partir disso, construir o novo, que é passível de respostas. É o que discute Bessa (2016, p. 22), ao dizer que "[...] todo enunciado tem uma índole dialógica e se produz orientado na atmosfera do já dito e na resposta antecipada do ouvinte", isto é, a compreensão de um enunciado é altamente responsiva, pois presume uma resposta.

A isso, chamamos de responsividade, princípio que atesta a natureza dialógica dos enunciados, dado que, quando enunciamos um discurso, estamos respondendo a outros discursos e fazendo emergir discursos outros [tantos], ou seja, todo enunciado advém de um dizer e emerge outros, que se constituem como réplica(s). Em resumo,

[...] todo enunciado deve ser visto antes de tudo como uma resposta aos enunciados precedentes de um determinado campo (aqui concebemos a palavra "resposta" no sentido mais amplo); ela os rejeita, confirma, completa, baseia-se neles, subentende-os como conhecidos, de certo modo os leva em conta. (BAKHTIN, 2016, p. 57).

O reconhecimento desse jogo dialógico entre o dado e o novo é pertinente para o trabalho de construção de sentidos, uma vez que nos possibilita visualizar as relações dialógicas que existem em um dado enunciado, a presença da voz do outro ou de uma pluralidade de vozes. Esta questão compreende uma outra, de grande relevância nos estudos de Bakhtin e seu Círculo, que é o estudo da ideologia: realidade constitutiva da linguagem e que precisa ser considerada na construção de sentidos, conforme veremos na seção seguinte. 


\section{A natureza ideológica da palavra}

Entre as discussões postas, está também a preocupação com a dimensão ideológica do signo linguístico. A linguagem, à medida que é responsiva, é também social, envolve juízos de valor, ideologia. Acerca disso, Miotello (2008) compreende que toda palavra é dotada de valores, de uma carga axiológica, que não pertence à palavra propriamente dita, mas ao uso que se faz dela na interação social, na relação entre o lá e o cá, entre o sujeito e o outro.

Em face do conceito de ideologia, o autor supracitado esclarece que, quebrando a tradição de ideologia como algo pronto e já dado, Bakhtin e seu Círculo tratam a ideologia em seu sentido concreto e dialético, relacionando-a com os signos, que não apenas refletem uma realidade física, material, como também refletem e refratam uma outra realidade, que é sempre nova. Assim, entendemos que a ideologia não se centra apenas na mente do homem, se está lá é porque foi motivada por relações sociais, que, partindo da visão supracitada, são também dialógicas.

Essa é uma questão amplamente tratada, em Marxismo e Filosofia da Linguagem, por Volóchinov (2018, p. 98-99), que acrescenta:

[...] A palavra é o fenômeno ideológico por excellence. Toda a sua realidade é integralmente absorvida na sua função de ser signo. Não há nada na palavra que permaneça indiferentemente a essa função e que não seja gerado por ela. A palavra é o medium mais apurado e sensível da comunicação social. (VOLÓCHINOV, 2018, p. 98-99).

Apesar da complexidade do conceito de ideologia, essas palavras nos levam a compreendê-la enquanto constitutiva da linguagem, realidade social que se refere à interação, pois, sempre que falamos/enunciamos, partimos de algo, de algum lugar, de alguma instância, por isso, todo signo é ideológico (VOLÓCHINOV, 2018).

Nesse sentido, Volóchinov (2018) compreende os signos como objetos físico-materiais que apresentam um ponto de vista e uma carga valorativa devido, em grande parte, à situação em que se inserem, passando a ser vistos enquanto objetos sócio-históricos, de domínio ideológico. Miotello (2008, p. 170) complementa essa ideia ao dizer que "[...] objetos materiais do mundo recebem função no conjunto da vida social, advindos de um grupo organizado no decorrer de suas relações sociais, e passam a significar além de suas próprias particularidades materiais". Acerca disso, tomemos como exemplo o signo "copo" que, perso- 
nalizado com a foto de alguém, passa a ser mais que um copo, possui uma carga valorativa que vai além do objeto enquanto signo físico-material.

Dito isso, entendemos a ideologia como princípio básico da constituição humana e, consequentemente, do discurso, visto que não existe ideia neutra. Os enunciados são, pois, construções de caráter ideológico, resultado das nossas práticas sociais. Cereja (2008, p. 204) reitera essa visão ao dizer que "[...] a palavra também é história, é ideologia, é luta social, já que ela é a síntese das práticas discursivas historicamente construídas".

Dessa forma, o modo de pensar dos sujeitos em sociedade é resultado das suas constantes interações sociais e dialógicas, que, mutuamente, se reconstroem e se ressignificam. A ideologia, portanto, é a representação social do mundo construído a partir das interações e das trocas simbólicas, constantemente atualizadas, por diferentes grupos sociais previamente organizados (MIOTELLO, 2008).

Assim, entendemos que, é graças à ideologia que as palavras adquirem sentido, uma vez que se considera o cronotopo da interação, isto é, o lugar social e histórico em que ela foi proferida. Como já afirmamos, o dialogismo pressupõe o enunciado como acontecimento que se dá na relação entre os indivíduos (interação), conforme suas posições sociais e suas valorações sobre o mundo (ideologia).

\section{Aspectos metodológicos}

O presente estudo configura-se como sendo uma pesquisa do tipo bibliográfica, de cunho qualitativo, de natureza exploratória e descritiva, que versa sobre um olhar interpretativo acerca do objeto de estudo. Utilizamos a teoria dialógica de Bakhtin como aporte teórico para a análise de quatro charges de cunho político, produzidas no mês de janeiro, do ano de 2020, veiculadas no Jornal FoIha de São Paulo [Folha Uol], as quais tratam sobre posicionamentos axiológicos de chargistas que escrevem em um jornal de grande circulação nacional sobre atitudes do Presidente da República.

A opção pelo Jornal Folha de São Paulo deu-se em face de ser uma das maiores mídias jornalísticas do país e de ter o acesso facilitado pelas tecnocologias. Selecionamos quatro charges que, de algum modo, elucidam uma imagem do presidente Jair Bolsonaro relacionada a questões de ordem econômica, cultural, ambiental e educacional. O interesse por temáticas diferenciadas justifica-se pela necessidade de conhecermos com maior afinco o posicionamento do go- 
verno federal acerca de assuntos de relevância e preocupação social.

O exercício de análise desse material visa construir compreensões no tocante à categoria dialogismo, observando as regularidades da teoria e as especificidades do gênero em estudo. Nisso, leva em conta muito mais o cronotopo de produção que os aspectos linguísticos da língua, como Bakhtin e o Círculo sugerem em seus estudos.

Partindo do pressuposto de que as questões propostas pelo filósofo e pelo Círculo não constituem categorias fechadas, principalmente o dialogismo, conceito basilar da teoria bakhtiniana, entendemos que a análise das relações dialógicas se inter-relacionam com a perspectiva ideológica/valorativa - ideologia -, por exemplo, outra questão abordada pelo Círculo e considerada na apreensão dos sentidos dos textos selecionados para análise.

Trabalhamos, conforme Pinheiro (2002), com o pressuposto teórico de que gênero se define social e historicamente, de modo a refletir a dinâmica e as características de uma sociedade e da cultura desta, especialmente em se tratando de textos que circulam na mídia. No que se refere à construção de sentidos em textos verbo-visuais, nesse caso, materializados no gênero charge, a sua natureza é complexa, uma vez que os elementos que constituem o gênero são diversos: as marcas linguísticas, caricaturas, elementos visuais, contexto extraverbal, entre outros que dialogam entre si neste processo de construção de sentidos.

A seguir, realizamos uma breve contextualização acerca da noção de gênero na perspectiva midiática e, dessa forma, partimos para a descrição e análise da construção dos efeitos de sentidos das charges, conforme postulados apresentados.

\section{Discurso e sociedade: relações dialógicas e construção de sentidos no gê- nero charge}

A noção de gênero vem sendo discutida desde a literatura clássica, de Aristóteles e Platão a Bakhtin, e atualmente por outros linguistas. Ao buscar uma definição que se aplique aos novos textos, sobretudo àqueles que circulam na mídia, Pinheiro (2002) observa que os estudos envolvendo textos e gêneros não se esgotam, seja nas pesquisas dos clássicos, seja nas desenvolvidas por autores contemporâneos. Os textos constroem-se e reconstroem-se em um processo dinâmico e dialógico: um surge a partir de outro que, complementando-se ou divergindo-se, estão em constante diálogo.

Bakhtin (2016), que também segue em direção oposta à classificação 
clássica de gênero, concebe-o como fenômeno da pluralidade. Para o filósofo, os gêneros primários são simples, em razão de emergir de situações imediatas de comunicação discursiva, enquanto os gêneros secundários são mais complexos, carecem, pois, de maior sistematização. Em Os gêneros do discurso, no processo de formação, os gêneros primários, quando se integram aos secundários, transformam-se dentro destes e passam a adquirir características próprias: "perdem o vínculo imediato com a realidade concreta e os enunciados reais alheios" (BAKHTIN, 2016, p. 15).

Sobre essa transmutação, Pinheiro (2002) alerta que esse afastamento dos gêneros midiáticos da natureza clássica dá-se também pela volubilidade de alguns desses textos. A charge, por exemplo, que surge no espaço e no tempo específicos, só será compreendida para os interlocutores que são conhecedores desse cronotopo, diferentemente de um interlocutor não familiarizado com o cronotopo da comunicação enunciativa. Apropriando-se da concepção de Pinheiro (2002, p. 287), os gêneros midiáticos podem ser definidos como a representação de "práticas socioculturais dentro de outras práticas socioculturais institucionalizadas" que envolvem interlocutores e são mediadas pelo texto, a partir do querer dizer do produtor e do que é interpretado pelo interlocutor.

Sobre a verbo-visualidade, Brait (2013, p. 62) corrobora que,

\begin{abstract}
enquanto conjunto e sob a perspectiva dialógica, o enunciado/texto verbo-visual caracteriza-se como dimensão enunciativo-discursiva reveladora de autoria [...], de diferentes tipos de interlocuções, de discursos, evidenciando relações mais ou menos tensas, entretecidas pelo face a face promovido entre verbal e visual, os quais se apresentam como alteridades que, ao se defrontarem, convocam memórias de sujeitos e de objetos, promovendo novas identidades. (BRAIT, 2013, p. 62).
\end{abstract}

De modo a apreender melhor as noções sobre o dialogismo, sobretudo como ele se desenvolve em textos verbo-visuais, elegemos quatro charges ${ }^{2}$ para análise. Nelas, observaremos a manifestação das relações dialógicas assumidas no funcionamento de cada uma das charges da Folha de São Paulo, procurando responder à seguinte pergunta: quais vozes dialogam com o enunciado? Isto é, com quais discursos já proferidos as charges dialogam? A seguir, vejamos a primeira delas: 


\section{Figura 01}
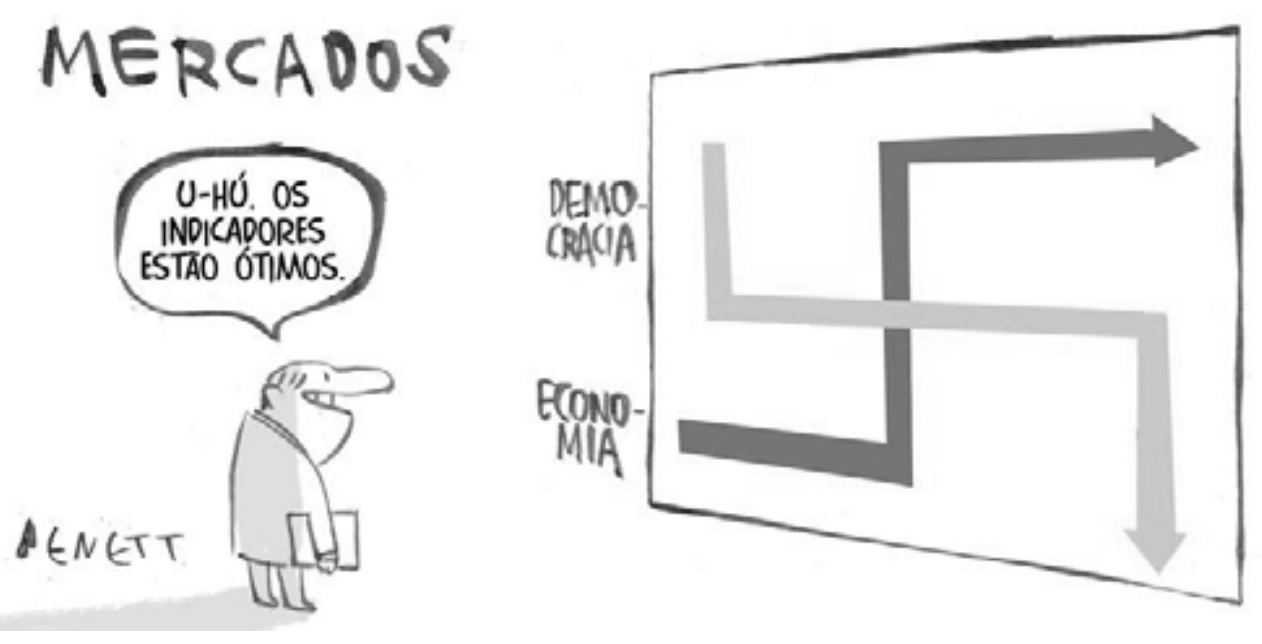

Fonte: Jornal Folha de São Paulo, 20 de janeiro de 2020.

A charge, de autoria de Alberto Benett, publicada por ocasião da veiculação de informações de que, ainda que lentamente, a economia no país apresentava crescimento, é uma resposta a essas notícias, esclarecendo que, em função desse crescimento, atitudes que ferem o direito democrático da população estavam sendo tomadas, tendo em vista que, em meses anteriores, o congresso nacional havia aprovado duas reformas que impactariam diretamente a vida do povo brasileiro, a reforma da previdência e a reforma tributária.

Para tanto, o texto apresenta um gráfico com duas setas que se entrecruzam: uma denominada "democracia" e a outra, "economia". À frente, há uma pessoa que observa e comemora o referido quadro político-social, fato percebido pelo emprego da interjeição e da afirmação de que os indicadores estão ótimos. Configura-se como uma sátira à atual economia brasileira, decorrente de um dado cenário político, sinalizada já em seu título "Mercados".

No tocante ao processo de semiose, voltando-se para o imagético, especialmente para o único recurso visual que, propositalmente, não aparece em preto e branco, como todo o restante do texto, observamos que os indicadores dos vetores "democracia" e "economia", por serem representados nas cores "amarelo" e "verde", respectivamente, acionam no leitor a mobilização de conhecimentos históricos, políticos e sociais, coletivamente compartilhados, considerando que tais cores, por ocuparem a maior parte da bandeira do país, simbolizam o patriotismo defendido pelo presidente Jair Bolsonaro.

Assim, dialogando com outros enunciados, observamos, por meio da as- 
similação dos elementos verbais e visuais, que o chargista expõe um juízo de valor ao cenário político e econômico do país. De modo mais específico, com os indicadores crescentes e decrescentes, da economia e da democracia, respectivamente, e com a alocução "u-hú. Os indicadores estão ótimos", o enunciador mostra que, na atual conjuntura política brasileira, em nome do crescimento da economia do país, são válidas atitudes que ferem o Estado democrático e que inibem a participação e a vontade popular nas decisões que afetam diretamente o povo. As setas, em posições contrárias, revelam uma forte crítica ao governo de Jair Bolsonaro.

Além disso, observamos que os vetores "democracia" e "economia" não são apresentados de modo aleatório, eles se expressam na materialidade textual fazendo uma explícita alusão à suástica da Alemanha Nazista, símbolo do nazismo. Com essa representação, o chargista ativa na memória social do interlocutor a figura de Adolf Hitler, para realizar uma crítica à economia e ao Estado democrático do Brasil, atualmente, governado por Jair Bolsonaro. Ao fazer isso, associa a figura do presidente a de Hittler, possivelmente, em razão de os dois líderes possuírem em comum certas características, a exemplo do valor que ambos dão à violência e à intolerância na resolução de conflitos ${ }^{3}$, à dominação e à imposição de sua figura como chefe soberano da nação.

Por todas essas observações, evidenciamos que a charge dialoga com outros discursos e enunciados que precisam, necessariamente, ser recuperados para a construção dos sentidos do texto. Decerto, argumentamos que, para as relações dialógicas serem apreendidas, faz-se necessário considerar que o texto se encontra socialmente situado no espaço e no tempo, em um dado cronotopo, é constituído por um conjunto de vozes e discursos já enunciados, isto é, parte do já dito, emergido pela materialidade linguística, por meio do verbal e do visual, no caso do gênero em estudo, e, ainda, que sua compreensão é altamente responsiva, a qual versa sob o olhar axiológico do enunciador.

Sob essa ótica, percebemos que, para o interlocutor dialogar com a charge em questão, assumindo uma postura responsiva ativa, ele precisa (re)conhecer o cronotopo de produção do texto - mobilizar conhecimentos históricos e discursos proferidos anteriormente com os quais o texto verbo-visual de Benett dialoga. Nesse sentido, é mister atentar-se para o caráter irônico da charge, ao comemorar a queda da democracia em favor do crescimento da economia, além

3 Na votação do impeachment da presidenta Dilma Rousseff, o presidente Jair Bolsonaro homenageou o torturador Carlos Alberto Brilhante Ustra, por sua atuação durante o período ditatorial brasileiro. 
de associar o caráter patriota, expresso no texto, pela utilização das cores representativas da nação brasileira, que ocupam a maior parte da bandeira do país: verde e amarelo. É preciso ainda reconhecer o símbolo do nazismo ao qual as setas verde e amarela fazem analogia, relacionando-o à figura de Adolf Hittler, por quem o atual presidente Jair Bolsonaro parece manter certa simpatia, haja vista os inúmeros discursos proferidos publicamente em exaltação a ditadores e torturadores.

Assim, com esta análise, demonstramos os meios pelos quais as relações dialógicas se manifestam na charge, com enunciados já ditos e com outros a serem proferidos, já que, no processo de interação, suscita respostas de potenciais interlocutores, que também dar-se-ão sob a forma de enunciados (BAKHTIN, 2016). Esta análise que ora desenvolvemos representa, a nosso ver, o querer dizer do locutor. Entretanto, outras poderão compreender e dialogar de forma diferente, levando em conta outros discursos e outros conhecimentos histórico-sociais situados.

Na sequência, apresentamos mais uma charge, também de teor político, que ilustra nitidamente o jogo dialógico da linguagem associado à sua dimensão ideológica.

\section{Figura 02}
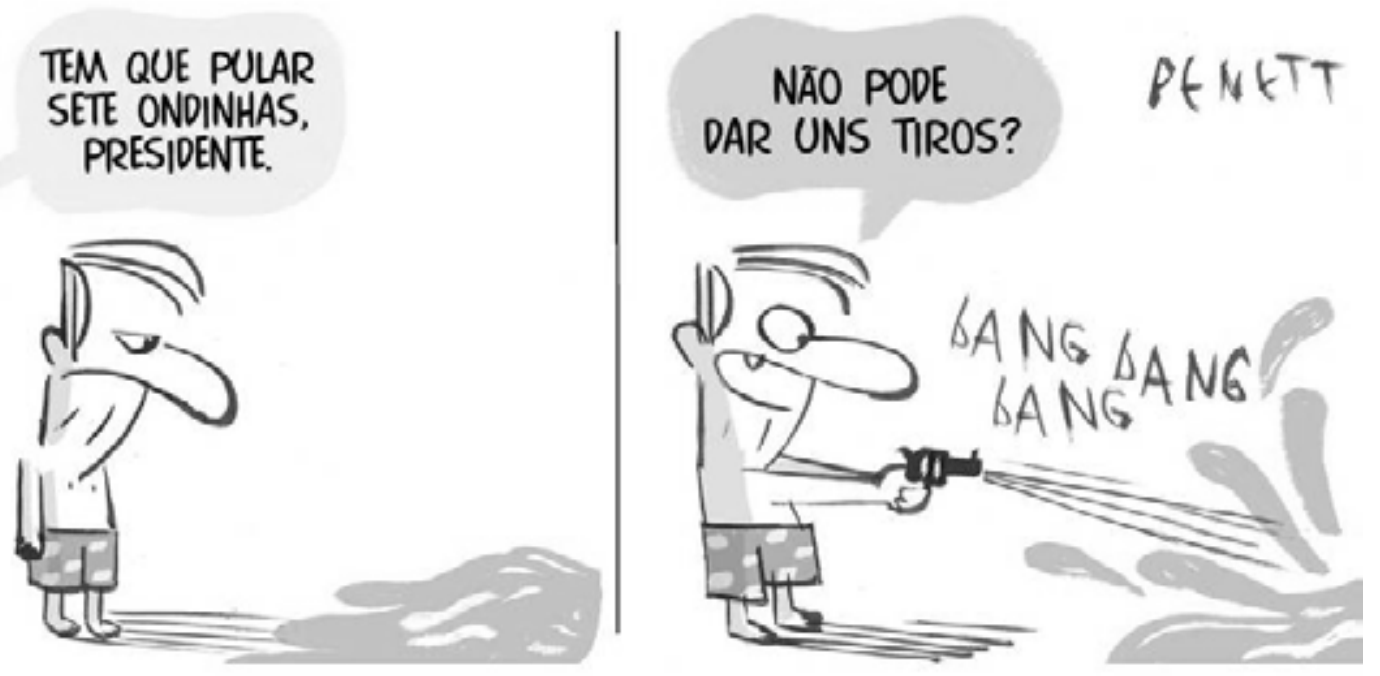

Fonte: Jornal Folha de São Paulo, 2 de janeiro de 2020.

Como vê-se, a charge de Alberto Benett foi publicada logo após o feriado de Ano Novo. Nela, vê-se, de frente para o mar, a caricatura de Jair Messias Bolso- 
naro. Em traje de praia, a figura do presidente é avisada, por uma voz, que deve pular sete ondinhas, porém, ele questiona se não poderia "dar uns tiros" em vez disso, já apontando a arma em direção às águas e atirando. O som do tiro é reproduzido pela onomatopeia "bang, bang, bang".

Observamos que a charge dialoga com a tradição popular brasileira, herdada da cultura africana, que diz que quem passa a virada de ano na praia, à meia-noite, deve entrar no mar e pular sete ondas. A cada onda que pular, em posição de frente para a água, a pessoa deve fazer um pedido ou externar um desejo. O propósito do ritual é o de afastar as energias negativas e o de ajudar a superar as adversidades que possivelmente virão no ano que se inicia.

No tocante à construção de sentidos do texto, é preciso levar em conta que o governo do presidente Bolsonaro enfrenta diversos conflitos nos mais variados ministérios. Em pouco mais de 01 (um) ano e 6 (seis) meses de exercício, já ocorreram inúmeros escândalos envolvendo a sua pessoa e a de familiares, como esposa e filhos, além de um quadro político marcado pela instabilidade e, por conseguinte, pela exoneração e pela nomeação de ministros e de outros cargos, a nível de primeiro e segundo escalões.

Assim, constatamos que a sugestão de pular sete ondinhas, expressa na charge, consiste em uma crítica ao governo atual, que enfrenta dificuldades e que, portanto, ironicamente, a adesão a essa crença traria mais sorte ao presidente, bem como ajudaria a solucionar seus problemas. Por outro lado, a expressão "dar uns tiros", ao invés dos pulinhos, dialoga com a imagem de Jair Bolsonaro, divulgada pela mídia e alimentada por ele próprio: homem que usa a força para a resolução de problemas e a repressão para inibir e corrigir determinados comportamentos, além de adepto da violência e defensor do uso e do porte de armas. Dito isto, nessa charge, propor usar a arma metaforiza a violência, propagada pelo atual presidente da república e, de certa forma, dialoga com o discurso do próprio presidente Bolsonaro que idealiza armar toda a sociedade brasileira.

Além disso, é de nossa interpretação que o signo "arma" posto na materialidade textual do gênero, na perspectiva do então presidente, possui uma carga valorativa que vai além do objeto enquanto signo físico-material, cuja função é matar. Com a charge e com vistas às observações feitas, entendemos que o presidente imprime, axiologicamente, afeto ao objeto discursivo "arma", como uma espécie de parceiro na solução de seus problemas, como se, com ela, tudo se resolvesse, a exemplo do "pular sete ondinhas".

Essa visão só é possível em razão do verbal e do imagético presentes no texto, especialmente, os diferentes estados de espírito da figura do presidente: 
insatisfeito no primeiro momento, possivelmente devido ao problema a ele imposto, e satisfeito no segundo momento da charge, em razão da sua resolução. A junção desses recursos mobiliza no leitor a ativação, na memória discursiva, de uma série de discursos e posicionamentos do presidente Jair Bolsonaro, já cristalizados socialmente, os quais o enunciador presume que o interlocutor tenha conhecimento, o que se faz necessário para a construção dos sentidos da charge, que resultam numa crítica social à figura do presidente Jair Bolsonaro.

Em outros termos, para a compreensão da charge, é preciso acionar diversos conhecimentos, a exemplo de uma crença do povo brasileiro, do contexto político local, da imagem que constitui o presidente, bem como da data em que o texto fora publicado. Isso corrobora com os postulados teóricos de Bakhtin (2003), que defende a necessidade de uma visão cronotópica a respeito da obra/ enunciado, levando em conta o tempo, o espaço e os sujeitos inseridos nas relações dialógicas discursivas. Essa visão é fundamental para que nele o gênero firme sua identidade, mantendo relações dialógicas com outros enunciados, isto é, o(s) discurso(s) que esse texto provoca surge $(\mathrm{m})$ como uma resposta a discursos anteriores, e que, consequentemente, fará(ão) emergir outros [tantos].

Em continuidade à análise dos textos verbo-visuais, vejamos o que sugere a charge a seguir:

\section{Figura 03}
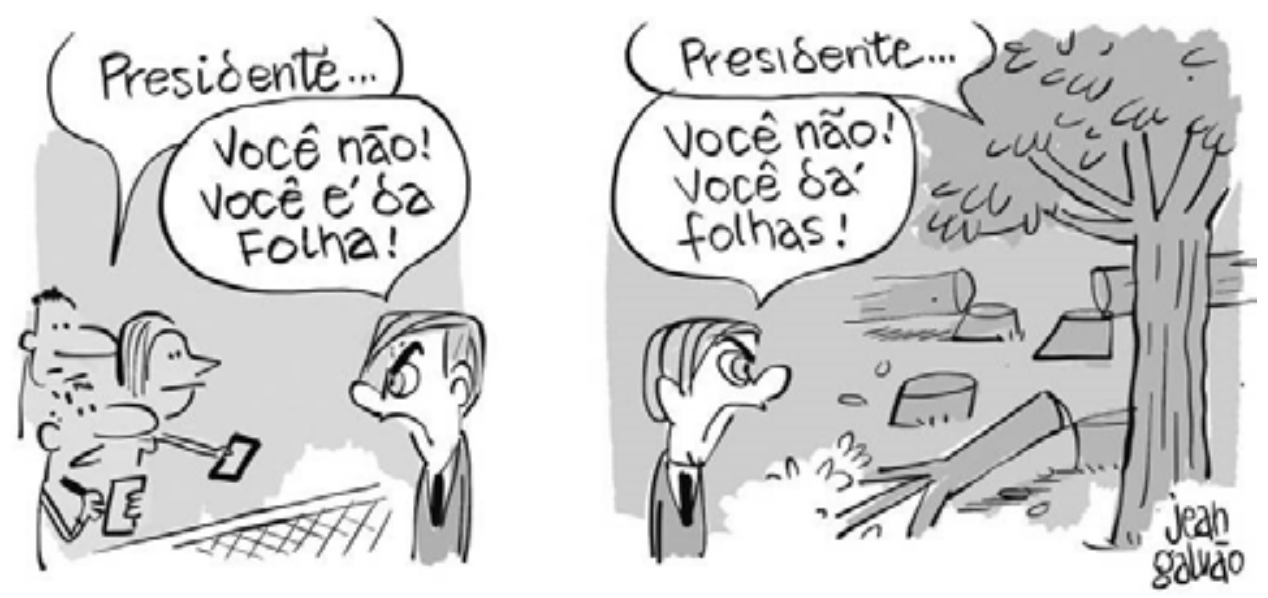

Fonte: Jornal Folha de São Paulo, 19 de janeiro de 2020.

Nesta charge, de autoria de Jean Galvão, temos, mais uma vez, a figura do presidente Jair Bolsonaro, agora em frente a um grupo de repórteres que pretendem entrevistá-lo. No primeiro quadro, um deles chama-o pelo nome de 
presidente e ele, sem hesitar, nega a concessão da entrevista, alegando ser o repórter do Jornal Folha. No segundo quadro, uma árvore, em meio a tantas outras cortadas, aparentemente sobrevivente do desmatamento, numa atitude personificada, invoca pelo presidente, que, indiferente à situação, se nega a intervir com a justificativa de que ela dá folhas.

Dito isso, entendemos que o chargista pretendeu ironizar a ausência de pronunciamentos do presidente em relação aos problemas que o país enfrenta, bem como de atitudes em relação ao desmatamento que ocorre no país, sobretudo na região amazônica, através do trocadilho com a polissemia da palavra "folha" que, em analogia à desarmonia política envolvendo o Jornal Folha de São Paulo e ao episódio das queimadas, se ressignifica de um momento para o outro.

Em relação à negação da entrevista ao Jornal supracitado, é válido destacar que o presidente desaprovou algumas reportagens publicadas por essa mídia, tanto que, por diversas vezes, fez severas críticas à Folha, acusando-a de publicar falsas notícias a seu respeito, além de desdenhar que o Jornal, por si mesmo, estaria se enfraquecendo. Assim, por analogia, o chargista Jean Galvão comparou a fisionomia raivosa do presidente a duas negativas: o pronunciamento ao Jornal Folha de São Paulo e a sua falta de atitude diante do problema do desmatamento que assolou a Amazônia durante todo o ano de 2019, inferindo um teor de raiva à natureza por causar um problema ao seu governo.

Essa visão demonstra que o cronotopo de produção dos enunciados é formado por e em razão de enunciados outros que prestam informações pertinentes ao leitor para, a partir de um agenciamento cognitivo social, completar seus sentidos (BAKHTIN, 2016). Isso porque se o interlocutor desconhece os fatos apresentados anteriormente, a interpretação da charge fica comprometida, ilustrando, assim, a natureza dialógica da linguagem, entre o dado e o novo, especificamente. Com efeito, quando desconsideradas as relações dialógicas inerentes ao texto, fica comprometido o processo de construção de sentidos deste.

Além disso, a análise acerca desta charge assegura o que Volóchinov (2018) defende: a ideologia, constitutiva da linguagem, é motivada por relações sociais, uma vez que o presidente nega fala às duas "folhas" movido por visões individuais de mundo e pontos de vista que muito falam sobre si. Ademais, atribui aos signos "Folha" e "folhas" uma carga axiológica negativa, objetos sócio-históricos que apresentam significados para além de suas próprias particularidades materiais: um Jornal de desprestígio e uma árvore geradora de problemas, respectivamente. Decerto, por esse horizonte interpretativo, vislumbramos a crítica do chargista 
ao presidente Jair Bolsonaro.

Nessa perspectiva, apresentamos a última charge, que ilustra, de modo ainda mais marcado, essa natureza ideológica da palavra, que também é dialógica, portanto. Vejamos:

Figura 04

\begin{tabular}{|c|c|c|c|c|}
\hline $\begin{array}{l}\text { TEM UM MONTÃO } \\
\text { DE AMONTOADO } \\
\text { DE PALAVRA } \\
\text { AQUi }\end{array}$ & $\begin{array}{l}\text { TEM QUE } \\
\text { SUAVIZAR } \\
\text { ISSO AÍ, } \\
\text { TSO }\end{array}$ & $\begin{array}{l}\text { FAZ UM } \\
\text { LiVRO DE } \\
\text { COLORIR }\end{array}$ & OU LARANJA! & $\begin{array}{l}\text { QUE TAL } \\
\text { UM LIVRO } \\
\text { DE LIGAR } \\
\text { DONTOS? }\end{array}$ \\
\hline $\begin{array}{l}\text { MAS É UM } \\
\text { LiVRO } \\
\text { DiDÁTTCO, } \\
\text { PRESTICATE, }\end{array}$ & $\begin{array}{l}\text { COLOCANDO } \\
\text { MAIS IMAGENS? }\end{array}$ & $\begin{array}{l}\text { MAS SEM } \\
\text { LAPIS } \\
\text { VERMELHC }\end{array}$ & $\begin{array}{l}\text { OU COR } \\
\text { HOMOSSEXUAL }\end{array}$ & t \\
\hline
\end{tabular}

Fonte: Jornal Folha de São Paulo, 6 de janeiro de 2020.

Na primeira semana de janeiro, do ano de 2020, João Montanaro publicou essa charge após o presidente Jair Bolsonaro afirmar que os livros didáticos possuem muitos textos e defender a necessidade de uma possível "suavização". $\mathrm{Na}$ ocasião, também informou que, a partir de 2021, sob sua gestão, quando da produção de novos livros, eles conterão na capa a bandeira do Brasil e o Hino Nacional.

Partindo dessa contextualização, o chargista apresenta, na materialidade textual do gênero, um diálogo entre Jair Bolsonaro e uma pessoa não identificada. Assumindo uma posição dotada de valores axiológicos, o presidente segura o livro aberto com as mãos e alega que contém um amontoado de palavras, insistindo ser necessário suavizá-lo, colocando mais imagens e, consequentemente, menos texto. Além disso, pede também para que seja feito um livro de colorir, mas sem usar a cor vermelha, representativa do Partido dos Trabalhadores (PT), tampouco a cor laranja, por remeter a pessoas consideradas laranjas neste governo, e qualquer outra que tivesse relação com o público homossexual, tendo em vista seu posicionamento contrário às minorias. Associado a isto, a pessoa, representada somente pela voz, ideologicamente contrária à do presidente, sugere 
que sejam feitos livros apenas para ligar pontos, já que seria inviável a produção de um livro que atendesse a todas as exigências do chefe do poder executivo. $O$ presidente exclama "táoquei", concordando com a sugestão.

Nessa acepção, o chargista, ao fazer menção aos desejos do presidente Jair Bolsonaro na escolha do livro, retrata uma pluralidade de vozes, que, ao serem percebidas, revelam, em grande parte, os sentidos do texto. Ademais, num horizonte ideológico, tais vozes revelam, pelo presidente, posicionamentos contrários à mídia, à preservação ambiental e às minorias, neste caso, poderíamos citar, para exemplicar, o discurso de homossexuais.

Com essa visão, ratificamos a natureza não neutra dos discursos, sua relação com a cultura e o mundo social de quem enuncia, possibilitando ao leitor/ interlocutor realizar juízos de valor. Isso porque, conforme discutido por Miotelo (2008), os enunciados partem sempre do lugar de fala que o sujeito ocupa, revelando suas ideologias, posicionamentos e visões de mundo.

Nesse sentido, a figura do presidente, na charge 4, dialoga com a imagem que ele próprio construiu ideologicamente sobre si, de alguém dotado de inquestionável honestidade e idoneidade, que repudia qualquer ato politicamente ligado a governos anteriores ao seu, sobretudo que estiveram envolvidos em escândalos midiáticos, acusados de corrupção, o que justifica o presidente definir-se como antipestista. O discurso de negação, na constituição dos livros didáticos, da utilização das cores vermelha, laranja ou ligadas à bandeira da homossexualidade possui uma carga axiológica de total rejeição a pessoas ligadas ao Partido dos Trabalhadores, que hoje representa a maior oposição política ao presidente, e aversão a grupos minoritários e/ou marginalizados, como é o caso de pessoas homossexuais, caracterizando, desse modo, uma postura preconceituosa e discriminatória.

À medida que o posicionamento de Jair Bolsonaro diminui grupos e situações com os quais ele não dialoga ideologicamente, o faz na tentativa de engrandecer sua imagem e de conseguir a adesão e o apoio de pessoas que dialogicamente concordam com sua postura. Ao nosso ver, o intuito do presidente é de que os brasileiros o vejam como um patriota, e que, em nome da nação e da religião, são válidas atitudes radicais e intolerantes, atribuindo um valor axiológico positivo a esses tipos de comportamentos.

Assim como a charge anterior, esta ilustra o caráter ideológico da palavra, pois a concepção de livro didático, de cores vermelha e laranja ou que remeta ao universo homossexual, imprime ao seu discurso um valor axiológico, reflexo de 
suas relações sociais. Entendemos, portanto, que o modo de pensar dos sujeitos é resultado das suas constantes interações sociais e dialógicas, daí a relação discurso e sociedade na construção de sentidos dos enunciados, uma vez que os sentidos expressos na materialidade linguística se constroem graças às relações dialógicas que estabelecem com o que é extralinguístico, histórico e social.

Dessa forma, evidencia-se, ainda, que o processo de construção de sentidos em um texto requer o estabelecimento de relações dialógicas entre os interlocutores, levando em consideração o tempo e o espaço, numa visão cronotópica, as diversas vozes que evoca, bem como a natureza social, histórica e ideológica dos enunciados. Os gêneros que se proliferam na sociedade, a exemplo dos midiáticos, mobilizam uma série de conhecimentos e de outros gêneros já institucionalizados para a construção de sentidos, tendo em vista seu caráter volúvel e multimodal.

\section{Considerações finais}

Pretendemos, com este artigo, através da eleição de quatro charges, descrever e analisar, a partir da manifestação das relações dialógicas, como os sentidos são construídos em charges da Folha de São Paulo.

Assim sendo, com este trabalho, constatamos que o gênero em questão possibilita observar a manifestação das relações dialógicas, a partir do (re)conhecimento do cronotopo, que situa e motiva a produção dos enunciados nele materializados, num processo de agenciamento da multiplicidade de vozes que evoca. Com efeito, o exercício da análise ilustra os postulados da literatura de que nenhum enunciado se centra no vazio, mas numa situação histórica e social, pois é fruto da interação dialógica com outros já existentes, suscitando outros, isto é, consiste numa resposta e fomenta outras. Além disso, vimos que a natureza ideológica da linguagem, perceptível nas posições sociais e valorações dos sujeitos sobre o mundo, adquiridas nas relações sociais (interação), é indispensável à construção dos efeitos de sentidos dos enunciados.

Com essa investigação, reforçamos, ainda, a tese de que as relações dialógicas presentes nos enunciados dar-se-ão de diferentes formas que, expressas na materialidade textual, denotam questões de caráter social e ideológico, especificamente, determinadas pelo contexto enunciativo. A partir do campo extralinguístico, considerar o contexto, o cronotopo e os sujeitos que constituem o enunciado é fundamental para a observação dessas relações dialógicas, sobretu- 
do entre a linguagem, o social e o cultural.

No caso em tela, apontamos, portanto, como resultado que as relações dialógicas agencionam a atividade de construção dos sentidos nas charges analisadas, tanto de quem as produz, por, inclusive, influenciar nas escolhas empreendidas para a composição dos enunciados, na medida que auxiliam na realização da intenção pretendida, quanto de quem as lê, em razão de possibilitar ao leitor identificar tal intenção. Daí a relevância das relações dialógicas para a construção dos sentidos dos textos/enunciados que, no caso em pauta, tematizam comportamentos (discursos) do presidente Jair Bolsonaro e integram de forma única e particular a cadeia da interação discursiva.

Longe de apresentarmos aqui um trabalho de escopo exaustivo a respeito das relações dialógicas, tema tão caro aos Estudos da Linguagem, dada a brevidade do gênero sob o qual nos expressamos, propomos expor uma discussão que direcione estudos posteriores acerca deste e de outros temas apresentados por Bakhtin, os quais versem sobre a linguagem. Isso porque, como explanado, observar as relações dialógicas materializadas em/nos textos contribui significativamente para ampliação dos estudos a respeito da linguagem e da compreensão da produção e construção de sentidos, consequentemente.

Em suma, os postulados de Bakhtin, aqui reportados, sugerem uma possível contribuição para a leitura e interpretação dos efeitos de sentidos de textos verbo-visuais, com foco no funcionamento do gênero charge de cunho político, muito embora a análise apresentada possa ser ampliada, a partir de outros olhares, em estudos posteriores.

\section{Referências}

BAKHTIN, M. O discurso em Dostoiévski. In: BAKHTIN, M. Problemas da poética de Dostoiévski. Tradução de Paulo Bezerra. 5. ed. Rio de Janeiro: Foroense Universitária, 2018. p. 207-211.

BAKHTIN, M. Os gêneros do discurso. Organização, tradução, posfácio e notas de Paulo Bezerra; notas da edição russa de Serguei Botcharov. São Paulo: Editora 34, 2016. p. 71-107.

BAKHTIN, M. Questões de literatura e de estética: a teoria do romance. Tradução de Aurora Fornoni Bernardini et al. 7. ed. São Paulo: HUCITEC, 2014.

BAKHTIN, M. Estética da criação verbal. Tradução de Paulo Bezerra. São Paulo: Martins Fontes, 2003.

BESSA, J. C. R. Das múltiplas facetas do dialogismo bakhtiniano: reflexões teóricas e um percurso analítico de estudo. In: FERREIRA, F. A.; LUDOVICE, C. A. B.; PERNAMBUCO, J. (org.). 0 texto: 
processos, práticas e abordagens teóricas. Franca, SP: Editora UNIFRAN, 2016. p. 15-43.

BRAIT, B. O texto nas reflexões de Bakhtin e do Círculo. In: BATISTA, R. de O. (org.). O texto e seus conceitos. 1. ed. São Paulo: Parábola Editorial, 2016. p. 13-30.

BRAIT, B. Olhar e ler: verbo-visualidade em perspectiva dialógica. Bakhtiniana, São Paulo, v. 8, n. 2, p. 43-66, jul./dez. 2013.

BRAIT, B.; CAMPOS, M. I. B. Da Rússia czarista à web. In: BRAIT, B. (org.). Bakhtin e o Círculo. São Paulo: Contexto, 2009. p. 15-30.

BRAIT, B. Bakhtin e a natureza constitutivamente dialógica da linguagem. In: BRAIT, B. (org.).

Bakhtin, dialogismo e construção de sentido. 2. ed. rev. Campinas/SP: Editora da UNICAMP, 2005. p. 87-98.

CEREJA, W. Significação e tema. In: BRAIT, B. (org.) Bakhtin: conceitos-chave. 4. ed. 2. reimp. São Paulo: Contexto, 2008. p. 201-220.

FLÔRES, Onici. A leitura da charge. Canoas: Editora da Ulbra, 2002.

MIOTELLO, V. Ideologia. In: BRAIT, B. (org.). Bakhtin: conceitos-chave. 4. ed. 2. reimp. São Paulo: Contexto, 2008, p. 167-176.

PINHEIRO, N. F. A noção de gênero para análise de textos midiáticos. In: MEURER, J. L.; MOTTA-ROTH, D. (org.). Gêneros textuais. Bauru, SP: EDUSC, 2002, p. 259-290.

VOLÓCHINOV, V. Marxismo e filosofia da linguagem: problemas fundamentais do método sociológico na ciência da linguagem. Tradução, notas e glossário de Sheila Grillo e Ekaterina VóIkova Américo; ensaio introdutório de Sheila Grillo. 2. ed. São Paulo: Editora 34, 2018.

\section{Sobre as autoras}

Amanda Mikaelly Nobre de Souza - Mestranda em Letras pelo Programa de PósGraduação em Letras (PPGL), pela mesma instituição, com bolsa CAPES vigente; Pau dos Ferros-RN; E-mail: amandasouza1997@outlook.com. Lattes: http://lattes.cnpq. br/4229604566438775. OrclD: http://orcid.org/0000-0003-3113-328X.

Ivaneide Gonçalves de Brito - Doutoranda em Letras pelo Programa de Pós-Graduação em Letras (PPGL), da Universidade do Estado do Rio Grande do Norte (UERN); Pau dos Ferros-RN; E-mail: ivaneidegbrito@hotmail.com. Lattes: http://lattes.cnpq. br/5351219813890609. OrclD: http://orcid.org/0000-0002-4449-0166.

Lidiane de Morais Diógenes Bezerra - Doutora em Estudos da Linguagem pela Universidade Federal do Rio Grande do Norte (UFRN). Professora Adjunto IV da Universidade do Estado do Rio Grande do Norte (UERN), Campus de Pau dos Ferros (CAPF). Docente permanente do Programa de Pós-Graduação em Letras (PPGL), pela mesma instituição. Pau dos Ferros- RN; E-mail: lidmoraisb@gmail.com. Lattes: http:// lattes.cnpq.br/4674844318235214. OrclD: http://orcid.org/0000-0002-9569-5567. 